\title{
ANALISIS ORGANOLEPTIK FORMULA MINUMAN KAHWA DAUN MIX
}

\author{
Rilma Novita ${ }^{1}$, Andi Eviza ${ }^{2}$, Jamal Husni ${ }^{3}$, dan Sri Kembaryanti Putri ${ }^{1}$ \\ ${ }^{1}$ Jurusan Teknologi Pertanian Politeknik Pertanian Negeri Payakumbuh \\ 2 Jurusan Budidaya Tanaman Perkebunan Politeknik Pertanian Negeri Payakumbuh \\ ${ }^{3}$ Dinas Kehutanan Propinsi Sumatera Barat \\ Email: rilma.novita@yahoo.com
}

\begin{abstract}
ABSTRAK
Penelitian dilakukan untuk mengetahui penerimaan panelis terhadap 3 formula minuman kahwa daun mix. Formula minuman kahwa daun mix terdiri dari bubuk kahwa daun, susu skim, krimer, dan gula pasir. Formula dibuat dengan memvariasikan berat bubuk kahwa dan susu skim sedangkan berat gula dan krimer dibuat tetap dengan berat total setiap formula 28 gram. Terhadap 3 formula (kode 135, $234,345)$ dilakukan uji hedonik meliputi warna, rasa, dan aroma oleh 25 orang panelis agak terlatih dengan 6 skala hedonik. Minuman kahwa daun mix dengan skor rata-rata penilaian tertinggi dari segi warna, rasa, dan aroma adalah formula 345. Hasil analisis dengan One Way ANOVA menunjukkan terdapat perbedaan yang nyata antar formula minuman dari segi warna (nilai sig $(\mathrm{P})<0.05)$ tetapi tidak terdapat perbedaan signifikan dari segi rasa dan aroma (nilai sig $(\mathrm{P})>0.05$ ).

Kata kunci- formula, hedonik, organoleptik
\end{abstract}

\section{PENDAHULUAN}

Kahwa daun adalah produk teh (teh herbal) yang dibuat dari daun kopi yang dikeringkan dengan cara didiang. Kahwa daun merupakan produk pangan kearian lokal dari Sumatera Barat. Kata kahwa sendiri berasal dari bahasa Arab yang artinya "kopi" Kahwa daun yang diseduh dengan air panas menghasilkan minuman yang disebut minuman kahwa daun atau masyarakat Sumatera Barat menyebut dengan nama "aia kawa" (Novita et al. 2015). Minuman kahwa daun disajikan dengan cangkir dari batok kelapa (tempurung) dan dituangkan dari tempat penyimpannya berupa "perian bambu" dengan tutupnya dari bahan "ijuk" (Zed, 2011).

Minuman kahwa daun mulai kembali dikembangkan pada tahun 2001 dan saat ini telah disajikan dalam beberapa varian diantaranya kahwa daun original, kahwa daun susu, kahwa daun susu telur, kahwa daun jahe dan kahwa daun kayu manis. Kahwa daun dengan varian rasa ini dapat dinikmati langsung di warung penjualan kahwa daun. Namun, waktu dan jarak menjadi sesuatu permasalahan yang harus diatasi bagi mereka yang tidak bisa datang langsung mencoba dan menikmati minuman kahwa daun. Olehsebab itu, produk pangan instan atau mix dapat menjadi salah satu solusi untuk menjawab permasalahan tersebut. Produk pangan instan didefinisikan sebagai produk dalam bentuk konsentrat atau terpekatkan dengan penghilangan air sehingga mudah ditambah air (dingin/panas), mudah larut dan siap disantap. Proses instan berjalan ideal apabila bubuk yang terkena media air menjadi basah dalam beberapa saat lalu tenggelam dan segera larut atau terdispersi secara merata dalam mediumnya (Hartomo dan Widiatmoko, 1992). Produk minuman instan yang populer diantaranya berbahan dasar kopi. Produk minuman instan merupakan produk yang berbentuk granular atau serbuk yang jika diseduh menghasilkan minuman tanpa ampas, sedangkan produk minuman mix adalah produk yang berbentuk serbuk dengan campuran bahan lain seperti krim, susu dan gula (Panggabean, 2011).

Teknologi pangan dapat mengeliminir halangan waktu dan jarak sehingga konsumen dapat menikmati citarasa makanan dan minuman tradisional menyerupai aroma dan citarasa aslinya. Berdasarkan latar belakang di atas maka dilakukan penelitian terhadap produk baru Minuman Kahwa Daun Mix (MKD Mix) sebagai salah satu bentuk produk pangan instan. Formula MKD Mix terdiri dari kahwa daun bubuk, krimer, susu skim, dan gula pasir. Penelitian ini bertujuan untuk mengetahui penerimaan panelis terhadap produk baru berbasis kahwa daun dengan uji hedonik. Uji hedonik merupakan salah satu jenis uji penerimaan. Panelis mengungkapkan kesukaan atau ketidaksukaan. Tingkat kesukaan disebut skala hedonik. Dalam analisis, skala hedonik ditransformasikan menjadi skala numerik dengan angka menaik menurut tingkat kesukaan. 


\section{METODOLOGI PENELITIAN}

\section{A. Waktu dan Tempat Penelitian}

Penelitian dilakukan di laboratorium Pengolahan Pangan dan laboratorium Penilaian Indrawi Politeknik Pertanian Negeri Payakumbuh pada bulan September-November 2016.

\section{B. Bahan dan Alat}

Bahan penelitian terdiri dari kahwa daun, krimer, susu skim, gula pasir, dan air mineral. Kahwa daun diperoleh dari produsen kahwa daun di Tabek Patah Kabupaten Tanah Datar Propinsi Sumatera Barat. Peralatan yang digunakan adalah : blender, timbangan analitik digital, timbangan, gelas ukur, gelas piala berbagai ukuran, penangas atau hot plate, pengaduk kaca, kertas saring Whatman, dan perangkat pengujian organoleptik berupa gelas, sendok, label, bilik pengujian dan form penilaian.

\section{Prosedur Penelitian}

1. Penyusunan formula

Penelitian diawali dengan penyusunan formula minuman yang terdiri dari kahwa daun, krimer, susu skim, dan gula pasir. Kahwa daun direduksi ukuran dan disaring dengan ayakan 60 mesh. Kahwa daun lolos ayakan digunakan dalam penyusunan formula. MKD mix disusun atas 3 formula. Formula minuman kahwa daun mix disajikan pada Tabel 1.

Tabel 1. Formula Minuman Kahwa Daun Mix

\begin{tabular}{lccc}
\hline \multirow{2}{*}{ Jenis Bahan } & \multicolumn{3}{c}{ Jumlah Bahan $(\mathrm{g})$ dan kode sampel } \\
\cline { 2 - 4 } & 135 & 234 & 345 \\
\hline Kahwa Daun & 2 & 4 & 6 \\
Krimer & 3 & 3 & 3 \\
Susu skim & 8 & 6 & 4 \\
Gula pasir & 15 & 15 & 15 \\
\hline \multicolumn{1}{c}{ Total $(\mathrm{g})$} & 28 & 28 & 28 \\
\hline
\end{tabular}

\section{Pembuatan minuman kahwa daun mix}

Satu formula memiliki berat 28 gram. Setiap 1 formula MKD mix diseduh dengan $180 \mathrm{ml}$ air bersuhu $90^{\circ} \mathrm{C}$, diaduk dan siap diuji organoleptik.

\section{Pengujian organoleptik}

Persiapan uji organoleptik meliputi persiapan panelis, sampel, dan laboratorium/ruang pengujian. Dalam penilaian organoleptik dikenal 7 macam panelis berdasarkan keahlian dalam melakukan penilaian organoleptik salah satunya panelis agak terlatih. Panelis agak terlatih dipilih dari kalangan tebatas yang sebelumnya dilatih untuk mengetahui sifat sensorik tertentu. Persiapan sampel sangat perlu mendapat perhatian dalam uji sensori. Persiapan dan penyajian sampel memperhatikan suhu, ukuran, kode, dan jumlah contoh saat pengujian. Berikutnya perlu diperhatikan ruang pengujian. Ruang pengujian merupakan ruang yang terisolasi dengan penyekat permanen atau penyekat sementara (Rahayu, 1998; Soekarto, 1985) .

Penelitian ini menggunakan panelis agak terlatih sebanyak 25 orang. Sampel yang akan diuji adalah 3 formula MKD mix dan masing-masing formula ditimbang sebanyak 56 gram (2 kali 28 gram) diseduh dengan $360 \mathrm{ml}$ air panas suhu $90^{\circ} \mathrm{C}$. Selanjutnya sampel didistribusikan ke dalam gelas pengujian organoleptik yang telah dilengkapi dengan kode 135, 234, 345 (25 gelas/kodel) dengan volume 5-15 ml per gelas. Setiap kode mewakili satu formula MKD mix. Kemudian sampel disajikan dalam ruang pengujian. Sampel disajikan secara bersamaan, 3 sampel diuji oleh 1 orang panelis di dalam satu bilik pengujian organoleptik. Panelis diberi penjelasan tentang form penilaian dan hal-hal penting lainnya saat melakukan uji organoleptik.

Uji organoleptik yang dipilih pada penelitian ini adalah uji hedonik atau uji kesukaan yang merupakan salah satu uji penerimaan. Panelis diminta menuliskan respon skala hedonik pada form yang telah disediakan dengan memberi tanda centang pada kotak sesuai dengan kesan yang 
dirasakannya/penilaiannya. Pada pengujian rasa, panelis dipastikan selalu meminum air putih sebelum berpindah dari satu formula kepada formula lainnya dalam pemberian kesan/penilaian.

\section{Analisis Data}

Analisis data dilakukan menggunakan analisis variansi (ANOVA) satu arah dengan program SPSS 16.0 Perbedaan antar rata-rata setiap perlakuan ditentukan dengan uji Duncan. Nilai P atau sig kecil dari $0.05(\mathrm{p}<0.05)$ dianggap mempunyai perbedaan signifikan secara statistik.

\section{HASIL DAN PEMBAHASAN}

Pengujian organoleptik MKD mix dilakukan dengan uji hedonik menggunakan 6 skala hedonik. Skala penilaian terdiri dari tidak suka (1), agak tidak suka (2), netral (3), agak suka (4), suka (5), dan sangat suka (6). Formula minuman disusun atas 4 komponen yaitu kahwa daun bubuk, krimer, susu skim, dan gula pasir. Satu MKD mix memiliki berat tetap yaitu 28 gram dan diseduh dengan air panas $180 \mathrm{ml}$. Panelis yang dilibatkan dalam uji organoleptik sebanyak 25 orang dengan kualifikasi panelis agak terlatih. Panelis diminta menuliskan tanggapan dan kesan terhadap warna, aroma, dan rasa ketiga formula MKD mix pada form yang telah disediakan dengan memberikan tanda centang pada kesan yang sesuai/dirasakan. Hasil uji hedonik terhadap 3 formula MKD mix disajikan pada gambar 1. Nilai rata-rata tertinggi dari segi warna, rasa dan aroma ditunjukkan oleh formula 345. Formula 345 terbuat dari 6 gram kahwa daun, 3 gram krimer, 4 gram susu skim dan 15 gram gula pasir.

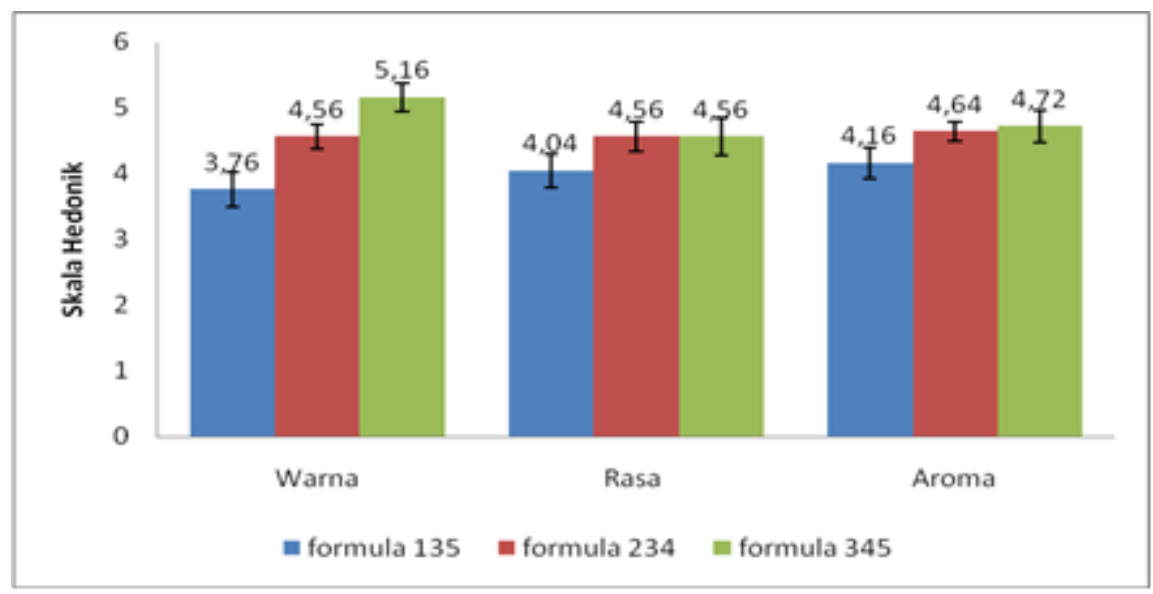

Gambar 1. Hasil Pengujian Organoleptik 3 Formula

Penilaian para panelis ditabulasikan dan dianalisis dengan program SPSS 16.0 menggunakan one way ANOVA. Dari tabel ANOVA diperoleh nilai sig $(\mathrm{P})<0.05$ yang artinya terdapat perbedaan signifikan diantara ketiga formula minuman dari segi warna. Selanjutnya, dari tabel ANOVA diperoleh nilai sig $(\mathrm{P})>0.05$ yang artinya tidak terdapat perbedaan signifikan dari segi aroma dan rasa diantara ketiga formula minuman. Hasil ANOVA disajikan pada Tabel 2.

Tabel 2. ANOVA Minuman Kahwa Daun Mix

\begin{tabular}{llrrrrr}
\hline & & Sum of Squares & df & Mean Square & F & Sig. \\
\hline respon_warna & Between Groups & 24.667 & 2 & 12.333 & 10.082 & .000 \\
& Within Groups & 88.080 & 72 & 1.223 & & \\
& Total & 112.747 & 74 & & & .257 \\
\cline { 2 - 7 } respon_rasa & Between Groups & 4.507 & 2 & 2.253 & 1.383 & \\
& Within Groups & 117.280 & 72 & 1.629 & & .141 \\
& Total & 121.787 & 74 & & & \\
\cline { 2 - 7 } respon_aroma & Between Groups & 4.587 & 2 & 2.293 & 2.010 & \\
& Within Groups & 82.160 & 72 & 1.141 & & \\
& Total & 86.747 & 74 & & & \\
\hline
\end{tabular}


Uji lanjut Duncan memberikan informasi formula yang berbeda nyata disajikan pada Tabel 3. Hasil uji Duncan diketahui bahwa minuman kahwa daun formula 135 berbeda dengan 234 dan 345 dari segi warna. Perbedaan warna minuman dapat dipengaruhi oleh kombinasi bahan penyusun minuman. Pemberian 2 gram kahwa daun dan 8 gram susu skim dalam formula memunculkan kesan yang berbeda dalam hal warna dibandingkan dua formula lainnya pemberian 4-6 gram kahwa daun dan susu skim. Formula 234 dan 345 memberikan warna coklat susu. Warna mempunyai peranan penting terhadap tingkat penerimaan produk secara visual. Suatu bahan pangan meskipun dinilai enak, tetapi memiliki warna yang tidak menarik atau memberi kesan telah menyimpang dari warna yang seharusnya, tidak menarik untuk dikonsumsi. Penentuan mutu suatu bahan pangan pada warna disebabkan warna adalah tampilan pertama yang terindera oleh konsumen (Winarno, 2002). Warna juga menandakan rasa suatu bahan pangan meskipun warna tidak selalu identik dengan rasa bahan pangan. Penyimpangan warna bahan pangan dari yang umumnya berlaku, dapat menyebabkanbahan pangan tidak akan dipilih konsumen meski masih dalam kondisi baik (Astawan, 2008).

Tabel 3. Hasil Uji Organoleptik

\begin{tabular}{cccc}
\hline FormulalPenilaian & Warna & Rasa & Aroma \\
\hline 135 & $3,76 \mathrm{a}$ & $4,04 \mathrm{a}$ & $4,16 \mathrm{a}$ \\
234 & $4,56 \mathrm{~b}$ & $4,56 \mathrm{a}$ & $4,64 \mathrm{a}$ \\
345 & $5,16 \mathrm{~b}$ & $4,56 \mathrm{a}$ & $4,72 \mathrm{a}$ \\
\hline
\end{tabular}

Angka yang diikuti oleh huruf kecil yang sama menunjukkan tidak berbeda nyata pada taraf $\alpha 5 \%$.

Tidak terdapat perbedaan signifikan diantara ketiga formula secara statistik dari segi rasa dan aroma. Hal ini dapat terjadi karena kondisi panelis yang melibatkan alat indera. Manusia yang dijadikan panelis terkadang memiliki kondisi fisik dan mental tertentu sehingga panelis menjadi jenuh dan kepekaan menurun, atau terjadi salah komunikasi antara manajer dan penelis (Meilgaaard et al. 1999). Untuk memperkecil kesalahan dalam analisis, maka dipastikan panelis berada dalam kondisi sehat dan prima. Secara keseluruhan baik formula 135, 234, 345 dapat diterima oleh panelis dengan rata-rata skala hedonik 4-5 (agak suka-suka).

\section{KESIMPULAN}

Minuman kahwa daun mix dengan skor rata-rata tertinggi uji hedonik dari segi warna, aroma, dan rasa adalah formula 345 yang terbuat dari 6 gram kahwa daun, 3 gram krimer, 4 gram susu skim dan 15 gram gula pasir. Hasil analisis dengan One Way ANOVA menunjukkan terdapat perbedaan yang nyata antar formula minuman dari segi warna (nilai sig $(\mathrm{P})<0.05)$ tetapi tidak terdapat perbedaan signifikan dari segi rasa dan aroma (nilai sig $(\mathrm{P})>0.05)$. Secara umum minuman kahwa daun mix dapat diterima oleh para panelis pada skala 4-5 (agak suka-suka).

\section{UCAPAN TERIMAKASIH}

Ucapan terima kasih disampaikan kepada Direktorat Jenderal Pendidikan Tinggi Kementrian Riset, Teknologi dan Pendidikan Tinggi yang telah membiayai penelitian ini melalui program Hibah Bersaing tahun 2015 sehingga penelitian ini dapat berjalan lancar.

\section{DAFTAR PUSTAKA}

Astawan, Made. 2008. Khasiat Warna-Warni Makanan. Jakarta: Gramedia Pustaka Utama.

Hartomo, A. and M. Widiatmoko. 1992. Emulsi dan Pangan Instan Berlesitin. Yogyakarta: Andi offset. Meilgaaard, Morten, Gail Vance Civille, and B. Thomas Carr. 1999. Sensory Evaluation Techniques. Third Edit. New York: CRC Press.

Novita, Rilma, Andi Eviza, and Sri K. Putri. 2015. Proses Pembuatan Minuman Kawa Daun Di Sumatera Barat. in Prosiding Seminar Nasional Ketahanan Pangan dan Pertanian Berkelanjutan. Politeknik Pertanian Negeri Payakumbuh. 
Jurnal Teknologi Pertanian Andalas Vol. 21, No.1, Maret 2017, ISSN 1410-1920, EISSN 2579-4019

Rilma Novita, Andi Eviza, Jamal Husni, dan Sri Kembaryanti Putri

Panggabean, Edy. 2011. Buku Pintar Kopi. Cetakan 1. Jakarta: AgroMedia Pustaka.

Rahayu, Winiati Pudji. 1998. Penuntun Praktikum Penilaian Organoleptik. Bogor: Jurusan Teknologi Pangan dan Gizi Fateta, IPB.

Soekarto, Soewarno T. 1985. Penilaian Organoleptik Untuk Industri Pangan dan Hasil Pertanian. Jakarta: Bhratara Karya Akasara.

Winarno, F. 2002. Kimia Pangan Dan Gizi. Jakarta: Gramedia Pustaka Utama.

Zed, Mestika. 2011. Dilema Ekonomi Melayu : Dari Melayu Kopidaun Hingga Kapitalisme Global. Innovatio X(2):209-23. 